\title{
Raskin Distribution In Islamic Economic Perspective
}

\author{
${ }^{1}$ Ismaulina, ${ }^{2}$ Liza Wahyuni \\ \{ismaulina@gmail.com\} \\ ${ }^{1,2}$ Faculty of Economics and Business Islam, IAIN Lhokseumawe, Lhokseumawe, Indonesia
}

\begin{abstract}
This research is field research (field research) with data result from observation, interview, and documentation. As for the result of the research, it was found that the mechanical distribution of Raskin in Blang Mangat subdistrict was done with a flat sharing system to Target Household (RTS) which has been registered as recipient of Raskin program and to every household in Blang Mangat sub-district. The reasons are: (1) Difficulty in Establishing Target Household (RTS), (2) Culture of Togetherness, (3) Social Jealousy, (4) Lack of Socialization and Information and (5) Tradition. The practice of distributing Raskin rice in the Meuraksa settlement, Blang Mangat sub-district with a flat sharing system is not legitimate since taking the property that should be the right of the people (the poor and the needy) is haram, therefore, the practice is not appropriate according to Islamic Economics.
\end{abstract}

Keywords: Distribution, Raskin, Islamic Economic, Fakir, Poor

\section{Introduction}

Rice is the staple food of most Indonesians. Associated with the large number of Indonesian population in the category of poor then the government established a program that aims to improve food security for the poor who made from raw rice.The program is a raskin (poor rice) program launched by the Government of Indonesia in 2002. This program is an implementation of the consistency of the government in order to fulfill the right of the people's food as an effort to accelerate poverty reduction. This is stipulated in Presidential Regulation No. 15/2010 concerning the Acceleration of Poverty Reduction and Presidential Instruction No. 3 of 2010 on Fair Development Program. Raskin's program is to subsidize rice to poor families or low-income families to improve the welfare as set out in the Preamble to the 1945 Constitution of the fourth paragraph. In the Raskin rice government rules should be distributed to poor and vulnerable poor or more properly called poor and fakir. They are the beneficiaries of raskin called the Beneficiary Target Household (RTS-PM). Then the RTS-PM raskin was determined based on Social Protection Program Data Collection (PPLS-2011) by the Central Bureau of Statistics (BPS).

In Islam poverty is translated as faqru. Meanwhile, according to syara', meaning faqir as people who need and weak and can not be asked for anything [1]. Islam commands Muslims to help the poor as the word of God in the Qur'an Surah Al-Baqarah verse 177. Imam Abu Hanifa, and Imam Syafi'i declared that he was worse than poor. Fakir defined people who have nothing (to meet their needs), or have something but not up to $1 / 2$ of nishab. While the poor are people who can only meet half or more than half of their needs, but can not meet all. 
In the Law of RI stated that the right of the poor and the poor in receiving Raskin is the same, amounting to $15 \mathrm{KG} / \mathrm{KK} / \mathrm{RTS} /$ month with the cost of rice redemption $\mathrm{Rp} 1,600 / \mathrm{kg}$ in accordance with applicable regulations. Lhokseumawe city government regulation has removed the cost of rice redeeming for poor families or Raskin a total of 7,549 households (KK). This new policy was adopted by the Lhokseumawe Municipal Government in an effort to ease the burden of poor families through the subsidy of regional funds. The city government (Pemko) also bear the cost of transporting rice from Bulog Lhokseumawe warehouse to their respective settlements [2]. However, the distribution of Raskin in Blang Mangat sub-district is not implemented in accordance with government regulations. The distribution is equally distributed to the local population and thus the poor can not meet their needs. We know that taking or taking others' rights is a sin. QS. Al-Nisa verse 29.

Research M. Dian Septian et al, states that the Raskin program is still less precise target and every year there is always a problem in the distribution of the field [3]. Therefore we do not realize that the citizens themselves are depriving the rights of the poor. Let's keep our own rights together and do not like to take the rights of others. All this can happen because of the lack of knowledge of the people, the lack of ethics in a person and not embedded Islamic Shari'a values in everyday life so that the rights of others are also his right.

\section{Theoretical basis}

\subsection{Islamic Economics}

Islamic Economics is an economic system based on the teachings and values of Islam, sourced from the Qur'an, as-Sunnah, ijma 'and qiyas.Landasan Theory. According to Anto [4], Islamic Economics is a science and application of guidance and shari'ah rules that prevent injustice in obtaining and using material resources to meet human needs and to carry out its obligations to God and society. Most Muslim economists understand Islamic economics as a theory and economic practice that avoids any transactions that contain elements of riba (interest), maisir (gambling) and gharar (speculation), avoiding an increase in the welfare of a person in a false way or harming others, emphasizing on justice aspects of efficiency, not investing and transactions on forbidden products, and striving to realize social welfare supported by zakat and other pious charities. The Qur'an gives economic laws that can create stability in the economy itself. QS. ar-Ruum: 39 and QS.al-Baqarah 27. The purpose of Islamic economics [5] is: Delivering the life of Islam in the economic field. Make us have a treasure with which we can worship such as zakat. Give solemnity to the community. To avoid sin together. To be self-sufficient. To utilize all sources of the earth so as not to waste. Paying for raw materials do not fall into the hands of the disobedient to God. Opening job opportunities to the community and addressing unemployment issues. And to be grateful for God's blessings.

\subsection{The Meaning of Distribution and Its Urgency}

Distribution according to the dictionary (distribution, delivery) to some people or to some places or the distribution of daily necessities (especially in times of emergency) by the government to civil servants, residents, and so on. The meaning of distribution in the Islamic economy is very broad, which includes regulating the ownership of elements of production and sources of wealth, [6]. Distribution verses are contained in the word of Allah among them 
QS. al-Anfal (8): 1, QS. al-Hashr (59): 7, QS. al-Hadid (57): 7 and QS. at-Taubah (9): 60 [7]. According to Shihab [8] the intent of the whole verse above, that property should not only be the property and power of a group of human beings but must be circulated in society so that it can be enjoyed by all members of society by still recognizing property rights and banning monopoly, there is an equitable distribution with no one side or group, and the distribution process can proceed fairly. From the beginning Islam established that property has a social function. Distribution of unfair and uneven property will make the rich get richer and the poor become poorer. Thus, the distribution pattern should prioritize the priority aspect based on need assessment.

The implementation of the Raskin program involves various institutions at all levels of government, with the Coordinating Ministry for People's Welfare (Menko Kesra) as the main responsibility of the program. Technically, the person responsible for implementing the distribution of rice up to the distribution point (generally in the village office) is bulog and the person responsible for delivering rice from the distribution point to every RTS-PM is the local government. And it involves dimensions of inter-institutional and intergovernmental, financial, and administrative relationships. This is in accordance with Raskin 2014 General Guidelines (Pedum) which states that the Raskin program performance indicator is achieving the "Six Right" target.

\subsection{Purpose of Distribution in Islamic Economics.}

The purpose of distribution in Islamic economics can be grouped into (a). the purpose of da'wah; in QS Ali Imran: 140. (b). The purpose of education; QS at-Taubah: 103 and manifest such good morality as giving, giving and giving priority to others. Purifying from the morally disobedient, like a miser, loba and selfish (selfish). (c) social objectives; ie Meet the needs of the needy, and live the principle of solidarity within the Muslim community. QS al-Baqarah 273. Strengthens the bond of love and affection among individuals and groups within society. Eradicate the causes of hatred in society, which will have an impact on the realization of security and public order, for example that the unfair distribution of income and wealth will impact the presence of poor groups and regions, and an increase in crime rates that impact on unrest. (d). economic goals. The mode of distribution that can realize the best level of economic prosperity for the people. QS al-Baqarah: 265. In Islam, everyone is prohibited from accumulating wealth because it can impede the smooth flow of goods distribution and disrupt economic stability, as well as in excessive and greedy attitudes. (Surat al-Humazah 1-3). Similarly, to give a living, to earn a living and to spend the wealth must be done with lawful and spend the treasure in the way of Allah SWT. Some rules of the instrument of wealth distribution in Islam [9].

\subsection{Fakir and Poor}

Imam al-Ghaziy classified the poor into two types, the poor and the poor. The needy are unemployed who, of course, have no income or possess $20 \%$ of the property for their basic needs. The poor are people who can only meet the 70\% of their life needs (at the level of the poverty line threshold). Al-Hishniy [10], defines the needy and poor as follows: Al-Fuqara, plural from the indigent. Where the limit of the indigent is the person who has no property and occupation, or has property and work but the result can not to meet his needs, such as someone who needs 10 dirhams, for example, but only has two dirhams. But Interesting is also examined, because there are poor people but must pay zakat, the trader whose turnover reaches nishab, then he must pay zakat even though at the same time he is poor. According to 
Kuncoro [11] poverty is defined as the inability to meet the minimum standard of living needs. Shaykh Muhammad ibn Sholih al-'Uthaymeen illustrates the difference between the poor and the poor, "We can estimate the limitations of the poor and the poor by looking at the monthly salary. If the salary in a year is 5000 riyals (Rp 12.5 million), while the needs of 10,000 riyals ( $\mathrm{Rp} 25$ million), in this condition someone is considered poor. Because he is only able to meet half of his needs. If the salary in a year is 4000 riyals ( $R p 10$ million), while his needs in a year 10,000 riyals ( $\operatorname{Rp} 25$ million), in this condition he is considered fakir. Similarly, when a person does not have work, then he is considered fakir.

In the Law of the Republic of Indonesia Article 3 Number 13 Year 2011 on the Handling of Poor. The rights of poor students [12]. The right of the poor in Islam is an essential right, because God affirms that in the wealth and income of a person, there is a right of the poor and needy [13] and QS adz-Dzariyat verse 19. Islam strongly defends the poor-fakir so it gives an indication that Raskin is indeed one of the right-poor. In addition, they also have rights in welfare covering the safety and security of life. Among the principles for prosperity is the guarantee of the right to justice [14]. The poor are also entitled to a job because work is a source of income for a person to meet the needs of himself and his family next work can foster self-confidence [15]. The state is responsible for meeting the basic needs of the community, especially the poor. According to Ibn Hazm the basic needs of one's life (ibid h. 134). These basic needs, including one of human rights in Islam. If he can not afford it with his skill and income for a cause, then the state is obliged to provide it. If not enough countries can levy taxes from the rich. (ibid h.158).

\subsection{Raskin Law}

Legislation legislation on which Raskin is based Rasmet General Guidelines 2013. Decree of the Coordinating Minister for People's Welfare No. 35 of 2008, on the Central Raskin Coordination Team. There are several elements in Raskin, including Raskin Implementation Guidelines, Provincial Raskin Program Coordination Team, Raskin Regional Division Team, Raskin Unit, District Raskin Coordination Team, Distribution Implementation, Distribution Point, Poor Household (RTM), Deliberation Village / Village, Rice Bulog Quality Standard, Raskin Community Complaint Unit (UPM). Not all Indonesians are entitled to Raskin, only those who are poor and food insecure in certain areas have the right to receive Raskin.

\subsection{Principle of Justice in Islamic Economics.}

The Islamic economic system is based on the principle of justice covering all basic aspects of the economy such as production, distribution, consumption and exchange [16]. The general economic policy according to Islamic teachings is distributive justice. As the word of Allah in the Qur'an of al-Hashr verse 7. The concept of other distributive Justice of Islam is rooted in the aspect of human comfort to Allah SWT and each other. QS. Ali-Imran verse 180. And QS. al-Hadiid verse 7. Islam requires every individual and society to respect human rights and oblige the rich to help or help those who are economically weak. Like orphans, elderly people and permanent disabilities. Furthermore Islam provides the solution in the form of zakat, infak and alms. The government is responsible for the realization of a minimum standard of living for all citizens.

In Islam there are two kinds of income distribution systems [17]. The economic distribution system in Islam also recognizes the distribution of inheritance. Where the distribution system is arranged in a complex and systematic in science faraidh. While the distribution of wealth in the form of waqf, varies and is not limited by the social status of a 
person, rich and poor or because of blood ties (nasab) and kinship. Sometimes waqf is in the form of public facilities. In Islamic teachings it also establishes four functions of economic activity for a person (ibid., P. 393).

\section{Methods}

The study was conducted in Blang Mangat sub-district, consisting of 3 settlements, and 22 gampongs. As seen in the Table 1 .

In general, the livelihoods of the people of Blang Mangat sub-district from fishing and farming, but there are also working in the office, a teacher and entrepreneur but there are very few. Type of research (field research). The method used is descriptive qualitative analysis, which describes and analyzes phenomena, events, social activities, attitudes, beliefs, perceptions, individual thoughts as well as groups. The data sources used are: Primary Data Source, obtained directly from geuchik and Tuha Peut Gampong in Kecamatan Blang Mangat. Secondary Data Sources obtained from literature, documents, archives, rules, reports and others concern the Rice for Poor Family Program (RASKIN). Data obtained by collecting through three methods, namely: Observation, Interview and Documentation. The techniques in analyzing the data are: Phase Reduction, Phase Display and Phase Veritifikasi withdrawal conclusion.

\section{Results and Discussion}

\subsection{Raskin distribution process in Kecamatan Blang Mangat.}

The Raskin distribution mechanism in Kecamatan Blang Mangat was conducted with a flat distribution system where Raskin rice was distributed not only to Target Households (RTS) that had been registered as Raskin recipients but also distributed to all residents such as $225 \mathrm{KK}$ registered Gampong Kuala RTS but distributed to the number of households in the gampong Kuala (281 KK), as well as in Gampong Jambo Mosque registered as Raskin recipients as many as 211 RTS but distributed to a number of families in the gampong (241 $\mathrm{KK}$ ) and similar thing also happened in Gampong- other gampongs, so that Raskin Rice should be received per RTS of 1 sack $(15 \mathrm{Kg})$ reduced to an average of $10 \mathrm{Kg}$. This is clearly not in accordance with the Raskin distribution rules.

There are several reasons for Geuchik sharing Raskin equally in Kecamatan Blang Mangat, among others: (1). The Difficulty of Determining the Target Household (RTS) [18]. In reality, it is rare for the people in Blang Mangat sub-district to meet all the poor criteria of BPS. For example there are still many families who do not have adequate housing and inadequate housing facilities such as the absence of toilet facilities.

Table 1. The names of Gampong in Kecamatan Blang Mangat

\begin{tabular}{|c|c|c|}
\hline \multicolumn{3}{|c|}{ Kecamatan Blang Mangat Lhokseumawe City } \\
\hline Settlements Meuraksa & $\begin{array}{c}\text { Settlements } \\
\text { Teungoh/Peuntuet }\end{array}$ & Settlements Mangat Makmu \\
\hline Kuala & Mane Kareung & Alu Liem \\
\hline
\end{tabular}




\begin{tabular}{llllll}
\hline $\mathbf{2}$ & Blang Cut & 2 & Asan Kareung & 2 & Blang Buloh \\
$\mathbf{3}$ & Jambo Mesjid & 3 & Rayeuk Kareung & 3 & Blang Weu Panjo \\
$\mathbf{4}$ & Jambo Timu & 4 & Blang Peunteut & 4 & Jeulikat \\
$\mathbf{5}$ & Tunong & 5 & Kumbang Peunteut & 5 & Blang Weu Baroh \\
$\mathbf{6}$ & Blang Teue & 6 & Mesjid Peunteut & 6 & Seuneubok \\
$\mathbf{7}$ & Teungoh & 7 & Ule Balang Mane & & \\
$\mathbf{8}$ & Baloi & 8 & Keude Peunteut & & \\
\hline \multicolumn{5}{l}{ Source: Data of Blang Mangat Head Office 2017 }
\end{tabular}

(bathing, washing, toilet), but almost all families even each family member has a motor vehicle whose value is clearly more than Rp 500,000, 00. Therefore, the gampong officials became difficult to determine which households really deserve Raskin. (2). Culture of Togetherness; The Blang Mangat sub-district community still upholds the culture of togetherness and mutual cooperation and they argue that Raskin rice should be distributed evenly so that the culture of togetherness is maintained. (3). Social jealousy; if Raskin rice is not shared evenly, there will be social jealousy and there will be turmoil or conflict between the people and the gampong officials, so that public order, calm and tranquility can not be well preserved. (4). Lack of Socialization and Information; The socialization of the Raskin program to the gampong officials has been done quite well. But not continued to the community in every residence in Blang Mangat District so the information received by the community about Raskin is minimal. All they know is limited to the receipt of "rice quota" given by the government and they do not know in detail about who is entitled to receive the rationed rice, and how much rice the ration is received. (5) Tradition; Raskin rice distribution with flat sharing system has been going on for years in Blang Mangat subdistrict and this is a tradition so to change the habit is difficult. It takes time and process long enough and sustainable in changing the paradigm of society.

In this research, Raskin's economic distribution of Islam is the author of analysis based on three aspects, namely: rights, distribution and maslahah. Rights Aspects; There are two substances of rights [19]. According to fiqh scholars, the emergence of rights is caused by five things [20]. In the process of distributing Raskin rice evenly in Blang Mangat subdistrict, the right to get the rice belongs to the right which is defined as the power of a good because the object that is the right of the problem is rice. Islam gives the freedom for every individual to exercise his rights in accordance with the will as long as it is not against the shari'ah and should not violate or interfere with the rights of others so that the protection of freedom in the exercise of personal rights must be in line with the rights of others and the general public. The process of distribution of Raskin in Blang Mangat subdistrict with a system for sharing has happened the use of rights that harm the rights or interests of others. As described in QS anNisaa: 29. Outwardly, people receive Raskin rice in a legitimate way and do not take the rights of others. However, when viewed from the essence of the Raskin program is to reduce the burden of expenditure of the poor and vulnerable poor then for people who are not poor is considered to have taken the rights of others. Because the rice that should be received by poor households amounting to $15 \mathrm{Kg}$ to be reduced which means that the rights received are also reduced. Such a Raskin distribution mechanism is not justified according to Islamic shari'ah.

In addition, most of the poor and vulnerable poor do not know in detail about the amount, price, and target according to Peduk, Juklak and Juknis Raskin. They take for granted Raskin rice which is distributed even though the amount is much less than the amount they should receive. All of this is a geuchik policy. Ignorance and acceptance of what it is certainly can not be said as an element of willingness to share rights with people who are not poor but rather as an element of compulsion. One of the principles in conducting economic activities according 
to Islamic shari'ah is the principle of willingness (like the likes). If there is an element of coercion then it is forbidden to do so because it is not in accordance with Islamic shari'ah. The rules of Raskin distribution can be analyzed by looking at the right of its social aspect, to the dimension of individual rights in the state. Raskin program is a form of government responsibility to meet the basic needs of the people in the form of rice to tackle the problem of poverty that occurred in Indonesia. In Islam, the state is responsible for providing equal legal protection for all people in fulfilling basic needs, especially the poor who have limitations in meeting their basic needs. This is consistent with the Hadith of the Prophet: "Whoever abandons the property, then it is for his heirs and whoever leaves a family who can not afford, then I will be responsible" [21]. Based on the above argument, it can be seen that the right to receive basic needs is the poor. Distribution aspect; Distribution means the distribution, distribution, delivery of merchandise or goods and services to consumers by producers and governments. The word distribution is synonymous with the word dulah in Arabic. Etymologically the word dulah means to keep spinning or moving things from one place to another. While in term dulah means a process of rotation or circulation that is constant without any obstacles [22]. There are several instruments of distribution in Islam, namely zakat, infaq, alms, livelihood, waqf, testament, ganimah, and fa'i. Then, all funds sourced from these distribution instruments are stored and managed by the State (baitulmal). Then the Funds are channeled to certain groups of people according to Islamic teachings and the posts. Among the most important is the group of people who get their rights from zakat post. QS. At-Taubah verse 60. Likewise from infaq and alms, livelihood, endowments, and so forth must also be channeled according to their respective posts. In the previous discussion has been described this commitment is one form of the State in the promotion of public prosperity through poverty alleviation programs. In Islam, the state can be devoted as the head of a family or a father. Just like a father who gives protection to his family, the state or leader is also obliged to give protection to its people especially to the poor. As contained in the Hadith narrated by Muttafaq 'Alaih [23].

Aspects of al-Maslahah; Al-Maslahah comes from the word saluha, yasluhu, salahan, means something good, worthy, and useful. Al-Maslahah means all actions that encourage the realization of human goodness [24]. Every law that is sanctioned by Allah both in the form of Alquran and al-Hadith has a purpose or purpose that contains benefit to mankind. Some Muslim scholars assume that Maslahah is the aim of syara 'law which means that maslahah is equated with maqasid al-syari'ah [25] (bring in the kebakan and avoid damage)

According to al-Ghazali, as quoted by Nasrun Haroen, the benefit that can be used as a basis for legalizing the law must meet several criteria [26]. Raskin rice distributed evenly to the people has eliminated kemashlahatan and brought kemudharatan, because they should receive Raskin intact. This eliminates the benefits of raskin rice itself. So the criteria of one, two or three are not fulfilled because it does not bring kemashlahatan, but it actually brings kemudharatan for the poor. When viewed from the eyes of harmony and tranquility can be said to bring kemashlahatan because of the creation of unity and unity between communities and strengthen the ropes of brotherhood in the neighborhood of gampong community but such a way harm the other side.

Islam obliges its people to help one another, it is the main character of sharia principles. QS. al-Maidah verse 2 . This life is very dangerous when we do arbitrary in seeking sustenance from God. It is unfair, if there are few people living in abundant profits, while many people are harmed. Life that is only based on personal interests or classes, will undoubtedly undermine the public order; thus fostering crime, poverty, ignorance and tyranny. What a terrible punishment God provides for those who rob people of their rights and eat their fellow's treasures in a way that 
is false. Based on the above explanation of the practice of equitable distribution of Raskin rice in Blang Mangat sub-district, there has been an illegal acquisition of property by taking the property which should be the right of the poor and needy. Therefore, the practice is not appropriate according to Islamic Economics. (Surat ash-Shu'ara: 88-89) and (Surah al-Mu'min: 52). To further analyze the problem of distribution practice for the average of Raskin rice in Blang Mangat subdistrict, the writer wants to analyze it based on the distribution principles in other Islamic economies: (a). Freedom; Freedom must be based on faith in God and should not be contrary to the syara 'provisions, including not eating or interfering with the rights and interests of others [9]. (b). Recognition of private and public ownership; Islam recognizes individual property rights, as well as community property. However, both private property and public property rights are not absolute. Both remain bound by syara 'law to realize the benefit and avoid damage [17]. Islam recognizes the rights of individuals to have as much wealth as they can. However, every individual must be restricted and subject to the rules of the shara 'in possession of the property so as not to harm the interests of others. Taking Raskin rice by the community in Kecamatan Blang Mangat which is not poor is one way to own property that is detrimental to the interests of others because with the division the basic needs of the poor can not be met properly because the rice they receive has been reduced in number.

Justice; The concept of distribution within Islam states that distribution must be an economic condition that satisfies the demands of equilibrium and justice. Therefore, Islam does not direct the vague distribution, the location of equity in Islam is justice on the basis of Maslahah [27]. Indeed justice in Islam is putting something in its place. Taking something that is not his right is a reflection of injustice. Therefore, the distribution of Raskin does not reflect the principle of justice in the absence of proper fulfillment of rights.

\section{Conclusion}

The distribution of Raskin rice in Blang Mangat sub-district is evenly distributed to the gampong community in fact not in accordance with the General Guidelines, the Implementation Guidelines, and the Raskin Technical Guidelines. However, these rules are ignored due to various reasons and considerations such as: the lack of information and socialization that the community receives about Raskin, the difficulty of determining poor households by category, and the demands of people to share Raskin rice evenly in order to avoid conflict and social jealousy between communities. The practice of distribution for the average of Raskin rice in Blang Mangat sub-district is illegal according to Islamic Shariah. The reason can be seen from three aspects, namely: from the aspect of the right there is a reduction of the quota that should be accepted by the poor, from the aspect of distribution is a violation of justice because Raskin rice is not given to the people who are entitled to receive it properly in accordance with the rules and the aspects of maslahah it also did not meet the criteria kemashlahatan because with such a division it makes kemudharatan for the poor due to unmet needs for rice and of course harm them. This distribution practice is illegal (not appropriate) with Islamic economics. 


\section{Suggestion}

All community in Blang Mangat sub-district should be collected and given detailed information about Raskin program to avoid misunderstanding in receiving information about Raskin. Furthermore, the gampong officials should be objective in determining the RTS by updating the local community data through the Raskin coordination team so as to distribute Raskin rice completely to the eligible recipients and this certainly does not lead to conflict and social jealousy.

\section{References}

[1] W. Wargadinata, Islam \& pengentasan kemiskinan. UIN-Maliki Press, 2011.

[2] N. Halimah, "Subsidi Raskin," Aceh Tribunnews, 24-Aug-2012.

[3] M. D. Septian, T. S. Bahri, and T. Makmur, "Analisis Efektivitas Dan Efisiensi Distribusi Beras Miskin (Raskin) Di Kecamatan Trienggadeng Kabupaten Pidie Jaya,” J. Agrisep, vol. 14, no. 1, pp. 70-78, 2013.

[4] M. B. H. Anton, "Pengantar Ekonomi Mikro Islam," Yogyakarta, Ekonisia, 2003.

[5] Mardani, Hukum Ekonomi Syariah di Indonesia. 2011.

[6] T. A. M. Sulaiman and A. U. Sitanggal, "Menanggulangi Krisis Ekonomi secara Islam," Bandung PT al-Ma 'arif, 1985.

[7] A. Rahmawaty, "Distribusi dalam Ekonomi Islam Upaya Pemerataan Kesesjahteraan Melalui Keadilan Distributif," Equilibrium, no. 1, 2013.

[8] M. Q. Shihab, “Tafsir Al-Misbah,” Jakarta Lentera Hati, vol. 2, 2002.

[9] A. Shadr and M. Baqir, "Buku Induk Ekonomi Islam Iqtishaduna," Jakarta Zahra Publ. House, 2008.

[10] T. Al-Hishniy, Kifayah al-Akhyar Fi Halli Gayatil Ikhtiyar. Beirut: Dar al-Kitab al-Ilmiyah, 2007.

[11] M. Kuncoro, Ekonomi Pembangunan (Teori, Masalah, dan kebijakan), IV. Yogyakarta.: UPP STIM YKPN, 2006.

[12] Fauzan, "Hak Fakir dan Miskin.” [Online]. Available: www.djpp.depkumham.go.id. [Accessed: 15-Dec-2017].

[13] F. Rahman, Doktrin Ekonomi Islam. Yogyakarta: PT. Dana Bakti Wakaf, 2006.

[14] M. D. Ali, Lembaga-lembaga Islam di Indonesia. Jakarta: PT. Raja Grafindo Persada, 2005.

[15] M. T. Hasan, Islam dalam Perspektif Sosio Kultural. Jakarta: Lantabora Press, 2005.

[16] M. S. Chaudhry, Sistem Ekonomi Islam; Prinsip Dasar. Jakarta: Kencana, 2012.

[17] Z. F. Chalil, Pemerataan distribusi kekayaan dalam ekonomi Islam. Jakarta: Erlangga, 2009.

[18] N. Sukmadinata, Metode Penelitian Pendidikan. Bandung: Remaja Rosdakarya, 2009.

[19] T. M. H. Ash-Shiddieqy, Pengantar Fiqh Muamalah. Semarang: Pustaka Rizki Putra, 2006.

[20] M. H. Ali, Berbagai macam transaksi dalam islam. Jakarta: Raja Grafindo Persada, 2007.

[21] I. Muslim, Shahih Muslim. Kairo: Darul Fikr, 2006.

[22] M. T. Qodratilah, Kamus Bahasa Indonesia Untuk Pelajar. Jakarta: Badan Pengembangan dan Pembinaan Bahasa, 2011.

[23] I. Bukhari, Sahih Bukhori. Cairo: Darul Fikr, 2005.

[24] S. Amir, "Ushul Fiqh," Jakarta Kencana Prenada Media Gr., 2008.

[25] J. 'Audah, Al-Maqasid Untuk Pemula. Yogyakarta: SUKA Press, 2013.

[26] N. Haroen, Ushul Fiqh. Jakarta: Logos Wacana Ilmu, 1997.

[27] L. Hakim, Prinsip-prinsip Ekonomi Islam. Jakarta: Erlangga, 2012. 